${ }^{1}$ Dnipro University of Technology, Dnipro, Ukraine

R. Tereshchuk ${ }^{1}$, O. Chahovets ${ }^{1}$

\title{
PARAMETERS OF ANCHORING SYSTEMS FOR FASTENING OF INCLINED WORKINGS
}

\author{
P.М. Терещук ${ }^{1}$, О.В. Чаговець ${ }^{1}$ \\ ${ }^{1}$ Національний технічний університет «Дніпровська політехніка», Дніпро, Україна
}

\section{ПАРАМЕТРИ АНКЕРНИХ СИСТЕМ ДЛЯ КРІПЛЕННЯ ПОХИЛИХ ВИРОБОК}

Purpose is to analyze a state of the boundary rock mass of an inclined anchored working with the use of mathematical modeling methods and to determine rational anchoring parameters as well as length of the anchors if they are placed deeper under the mining and geological conditions of $l_{3}$ seam in Novodonetska mine (DTEK Dobropilliavuhillia JSC).

Research methods. Parameters of anchoring systems for the inclined workings were substantiated while studying regularities of changes in the behaviour of the rock mass as well as its stress-strain state and determining displacements of rock boundary of the working. The data have been used to define rational anchor length and anchoring density. Finite-element method has been used to analyze changes in the behaviour of the boundary rock mass of the inclined anchored working as well as its stress-strain state.

Findings. Analytical scheme has been originated to solve the problem concerning determination of rational anchoring density and anchor length to fasten inclined workings if they are placed deeper under the mining and geological conditions of $l_{3}$ seam in Novodonetska mine. Rational parameters have been identified to fasten the inclined workings under the specific mining and geological conditions.

Scientific novelty. Dependency graphs of displacements of the inclined working roof and floor upon its depth in the process of anchor length varying and anchoring density have been developed for mining and geological conditions of $l_{3}$ seam in Novodonetska mine.

Practical implications. The findings may be applied at the design stage to forecast displacements of roof, floor, and walls of the inclined workings under mining and geological conditions of $l_{3}$ seam in Novodonetska mine to optimize parameters of anchoring systems.

Keywords: inclined working, mathematical modeling, anchoring, density, length.

Introduction. A problem of maintainability of mine workings during the whole period of their targeted use is one of the basic factors determining a state of coal industry as well as its future. Operational upset of workings results in the loss of productive capability of enterprises i.e. decreases actual mineral output while increasing its prime cost.

The problem of stability of workings of coal mines becomes even more important with mining deepening since it factors into rock pressure increase stipulating significant deformation of supports of the workings.

To provide operational state of mine workings, coal mines should perform maintenance activities which are complete retimbering of certain sites or the whole mine working; replacement of the deformed support elements; use of short-term reinforcing support; increased density of frames; replacement of support lagging; blasting of the expanded floor rocks etc. 
The problem can be solved partially at the initial stage of a mine working construction while using a potential of the rock mass, i.e. increase in its bearing capacity being implemented by means of basic support-rock mass-extra measures system development. The latter is possible by means of the use of protective measures aimed at the inclusion of a boundary rock mass in the common activities with protective structures. Anchoring is one of the appropriate support types [1]. In this context, the key task is to calculate correctly its operational parameters.

Analysis of research and publications. The performed analysis of the available concepts, concerning anchoring-boundary rock mass interaction as well as methods to determine anchoring parameters, has shown that despite the variety and a number of the performed studies [2-4] the rock-anchor structure effect on geomechanical processes, taking place within a rock mass enclosing the mine working, is understudied.

Many hypotheses, concerning operation of the anchored mine working roof, are known. However, the available techniques and methods to determine basic parameters of anchoring (i.e. analytical, graphical, energetical and others), based upon the assumptions, prevent from complete and scientifically-based solving the problem of selection of anchoring parameters for the inclined workings depending upon different mining and geological conditions.

Even regulations concerning the use of anchoring systems in mine workings cannot give a straight answer as for the anchoring parameters under the complicated and extremely complicated mining and geological conditions of coal mines [5].

Numerous analytical and full-scale studies have been carried out for mining and geological conditions of DTEK Dobropilliavuhillia JSC mines. The studies are aimed at the analysis of parameters of anchoring systems set up within the nonhomogeneous boundary rock of the inclined workings. Regularities of changes in stress-strain state of a boundary rock mass of the inclined anchored workings and dependences of displacements of roof and floor of the inclined working when length and number of anchor set up within the boundary rock mass vary as well as the depth of a mine working have been obtained. Rational anchoring parameters for $m_{5}^{16}[6]$ and $m_{4}^{0}$ [7] seams (Dobropilska mine), $l_{8}$ [8] seam (Bilozerska mine), $m_{4}^{2}$ [9] seam (Pioner mine), and $k_{7}$ [10] seam (Novodonetska mine) have been determined.

The problem definition. It is required to analyze a state of the boundary rock mass of the inclined anchored working with the help of methods of mathematical modeling and to determine rational anchoring density as well as length of the anchors if they are placed deeper under the mining and geological conditions of $l_{3}$ seam in Novodonetska mine (DTEK Dobropilliavuhillia JSC) basing upon the research findings.

Statement of the basic material and the research findings. Parameters of anchoring systems for the inclined workings were substantiated while studying regularities of changes in the behaviour of the rock mass as well as its stress-strain state, and determining displacements of rock boundary of the working. The data were used to determine rational anchor length as well as anchoring density. 
Finite-element method has been used to analyze changes in the behaviour of the boundary rock mass of the inclined anchored working. Mathematical model of anchoring system-rock mass interaction was implemented with the help of elastic-plastic problem solving by the analogy with [6-10] papers.

The research involved modeling of mining and geological conditions of a benchlike slope of $l_{3}$ seam in Novodonetska mine (DTEK Dobropilliavuhillia JSC).

The $l_{3}$ seam is of complex structure. It consists of three coal plies separated by argillite and aleurite beds with 0.04 and $0.06 \mathrm{~m}$ thickness respectively. Thickness of the coal plies varies as follows: upper ply $-0.15-0.67 \mathrm{~m}, 0.47 \mathrm{~m}$ in the mean; central ply $0.28-0.33 \mathrm{~m}, 0.33 \mathrm{~m}$ in the mean; and lower ply $-0.60-0.83 \mathrm{~m}, 0.71 \mathrm{~m}$ in the mean.

The coal seam is continuous, undulated, and flat. Its angle is $13^{\circ}$. Tectonics of the seam is simple, and hypsometry of its floor is undulating.

Within the whole site, immediate seam roof is represented by argillite with up to 3.8 $\mathrm{m}$ thickness. It is grey, nonstratified, loose, broken, and soft. Tensile strength in uniaxial compression is $32 \mathrm{MPa}$. Thin $0.09-0.16 \mathrm{~m}$ aleurite vein occurs right above the seam.

The main roof of the seam is represented by aleurite layer which total thickness is up to $23 \mathrm{~m}$. The aleurite is grey and stratified. Tensile strength in uniaxial compression is $39 \mathrm{MPa}$.

Within the site, argillite with up to $2.5 \mathrm{~m}$ thickness is the immediate floor of the seam. The argillite is grey, nonstratified, loose, broken, and soft. Tensile strength in uniaxial compression is $25 \mathrm{MPa}$.

The main floor is aleurite with up to $8.9 \mathrm{~m}$ thickness. Tensile strength in uniaxial compression is $44 \mathrm{MPa}$. The aleurite is light grey, lamellar, solid, and stable.

Mathematical modeling of anchoring systems to fasten the inclined workings determined rational anchoring density and anchor length depending upon the mine working depth and in terms of parameter variations like in [6-10] papers. Fig. 1 demonstrates analytical scheme to solve the problem.

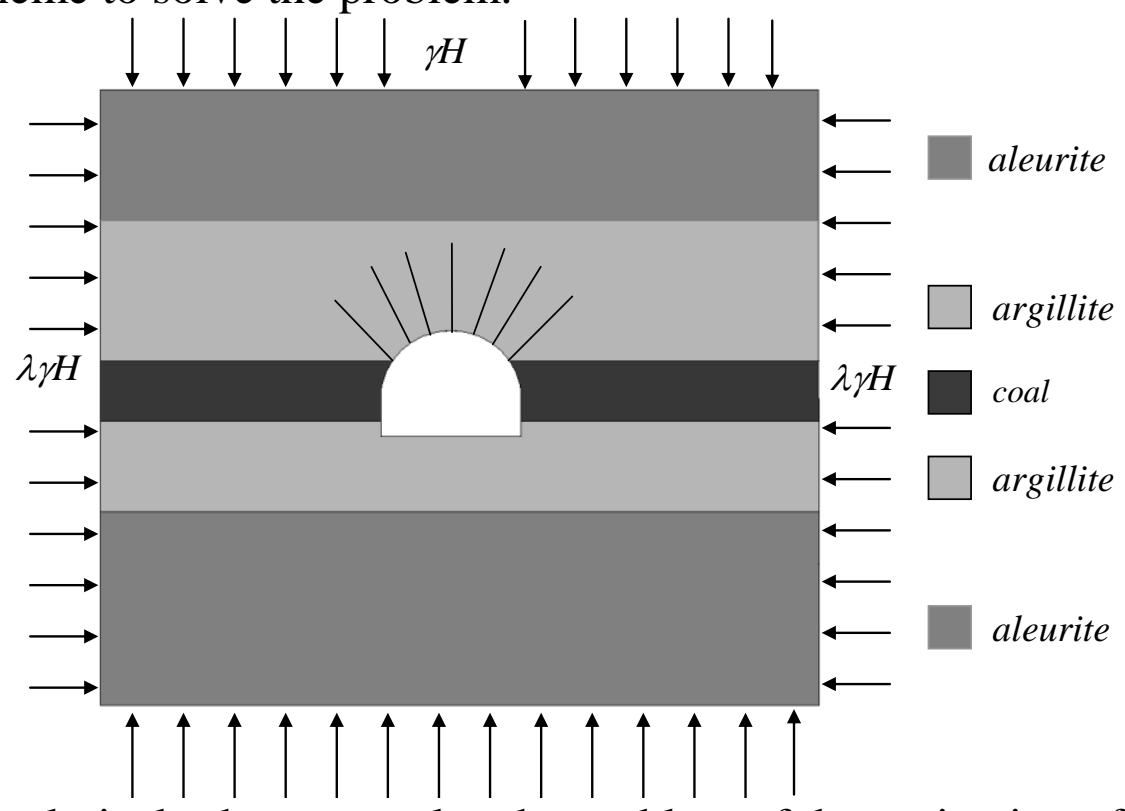

Fig. 1. Analytical scheme to solve the problem of determination of anchoring parameters for the inclined workings driven under the conditions of $l_{3}$ seam in Novodonetska mine 
Dependences of displacement values of boundary rock mass (i.e. roof and floor of the mine working) have become a result of mathematical modeling of the anchored bench-like slope of $l_{3}$ seam of level $580 \mathrm{~m}$ in Novodonetska mine in terms of variation of anchoring parameters from 3 to 9 anchors and from 2.2 to $3.5 \mathrm{~m}$ as well as 700 to $1500 \mathrm{~m}$ setting-up. The paper demonstrates dependence graphs of changes in displacements of the mine working roof and floor: upon the depth of its setting-up when 2.2 and $3.5 \mathrm{~m}$ anchors are applied (Figures 2-5); upon anchor length when the mine working depths are 700 and $1500 \mathrm{~m}$ (Figures 6 and 7); and upon anchoring density when the mine working depths are 700 and $1500 \mathrm{~m}$ too (Figures 8 and 9).

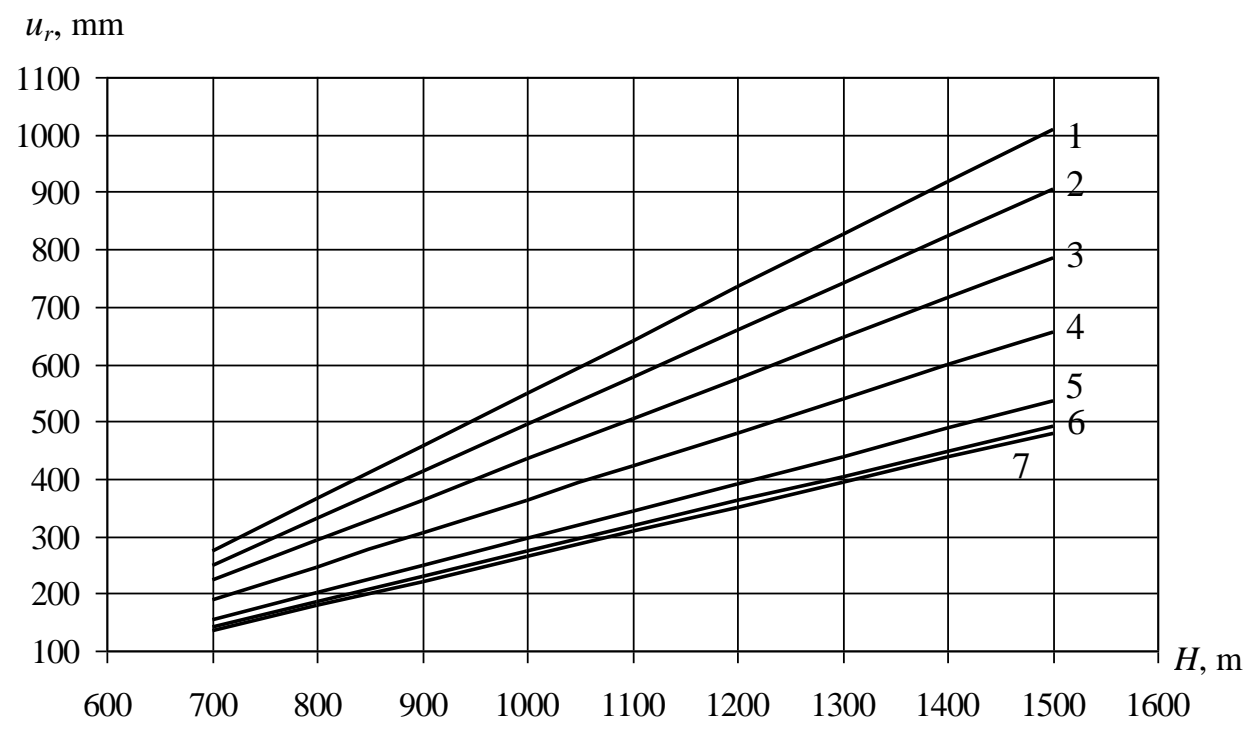

Fig. 2. Graphs of changes in the roof displacement values depending upon the mine working depth if anchor length is $2.2 \mathrm{~m}: 1-3$ anchors, $2-4$ anchors, $3-5$ anchors, $4-6$ anchors, $5-7$ anchors, $6-8$ anchors, $7-9$ anchors

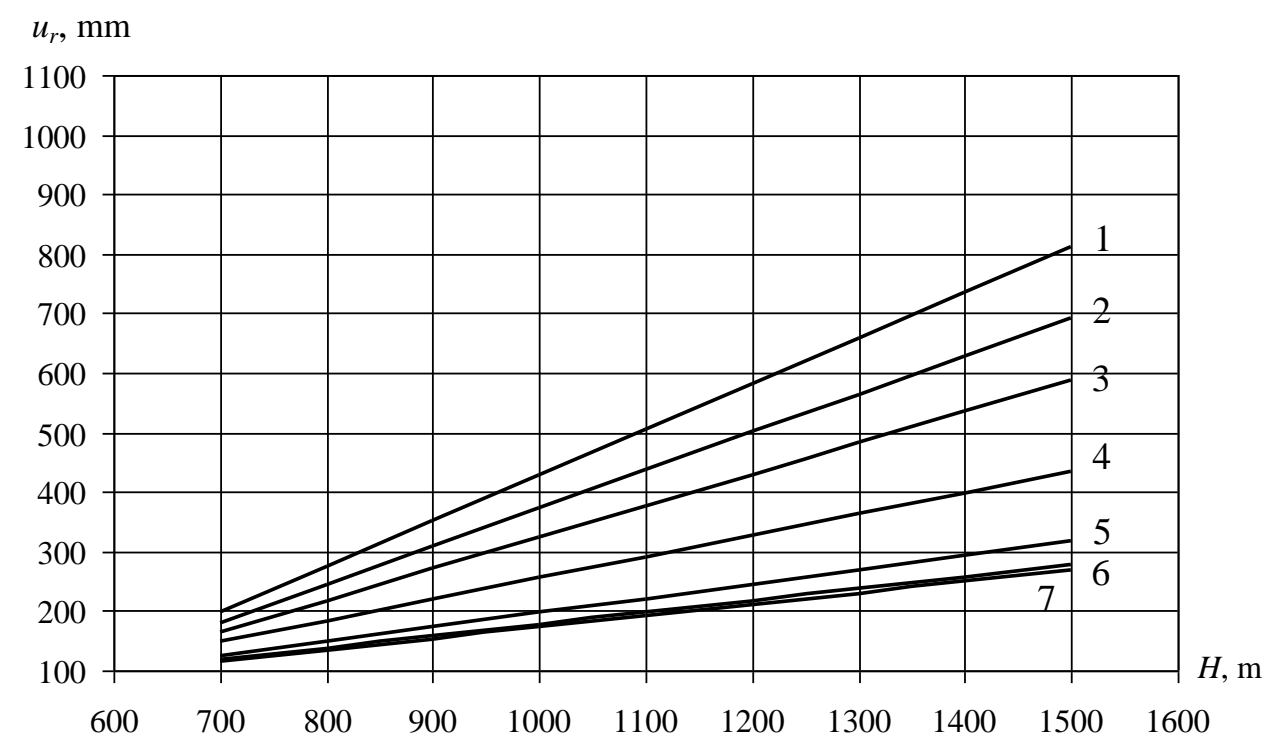

Fig. 3. Graphs of changes in the roof displacement values depending upon the mine working depth if anchor length is $3.5 \mathrm{~m}$ : $1-3$ anchors, $2-4$ anchors, $3-5$ anchors, 4 -6 anchors, $5-7$ anchors, $6-8$ anchors, $7-9$ anchors 
Analysis of the obtained results is as follows:

- in terms of $100 \mathrm{~m}$ deepening and use of 2.2, 2.5,3.0, and $3.5 \mathrm{~m}$ anchors, the roof displacement values are: 92, 84, 77, and $77 \mathrm{~mm}$ for 3 anchors; 71, 62, 53, and $53 \mathrm{~mm}$ for 5 anchors; 48, 36, 24, and $24 \mathrm{~mm}$ for 7 anchors; and 43, 32, 19, and $19 \mathrm{~mm}$ for 9 anchors respectively (Figures 2 and 3);

- in terms of $100 \mathrm{~m}$ deepening and use of $2.2,2.5,3.0$, and $3.5 \mathrm{~m}$ anchors, the floor displacement values are: 133, 124, 114, and 114 мм для 3 anchors; 115, 110, 102, and $102 \mathrm{~mm}$ for 5 anchors; 93, 89, 86, and $85 \mathrm{~mm}$ for 7 anchors; and 88, 85, 82, and $82 \mathrm{~mm}$ for 9 anchors respectively (Figures 4 and 5);

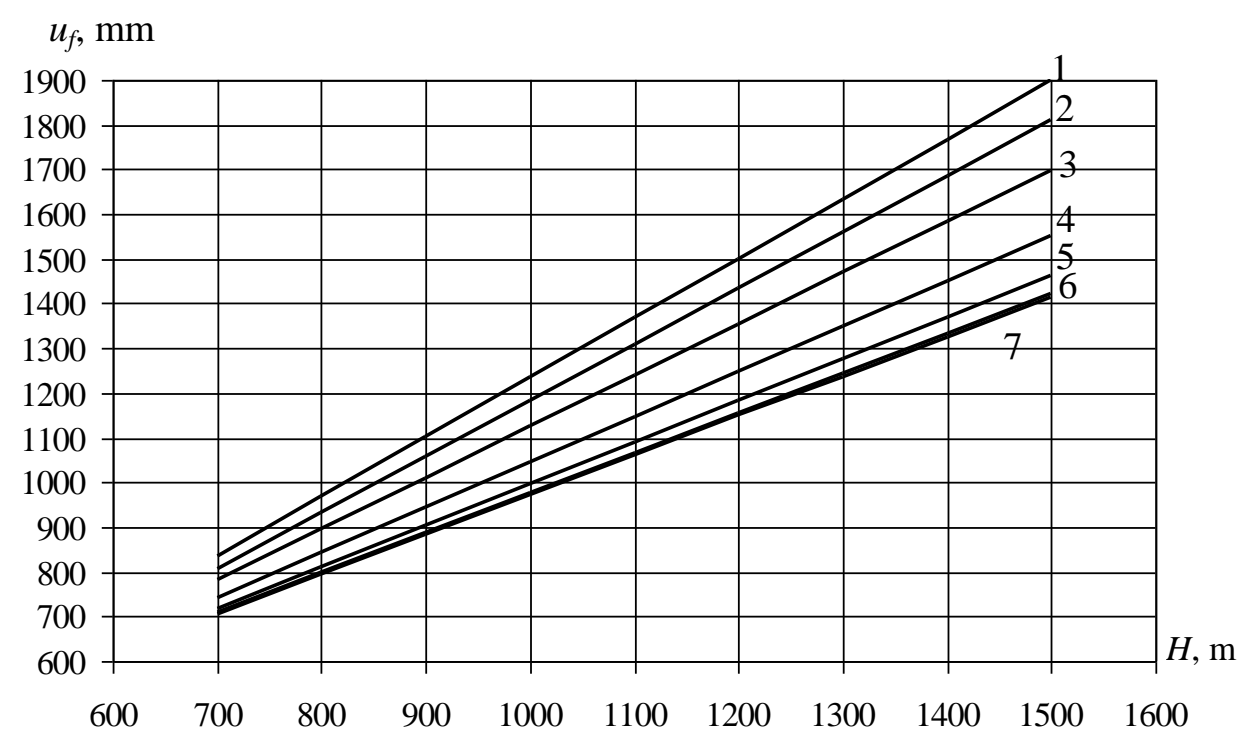

Fig. 4. Graphs of changes in the floor displacement values depending upon the mine working depth if anchor length is $2.2 \mathrm{~m}: 1-3$ anchors, $2-4$ anchors, $3-5$ anchors, $4-6$ anchors, $5-7$ anchors, $6-8$ anchors, $7-9$ anchors $u_{f}, \mathrm{~mm}$

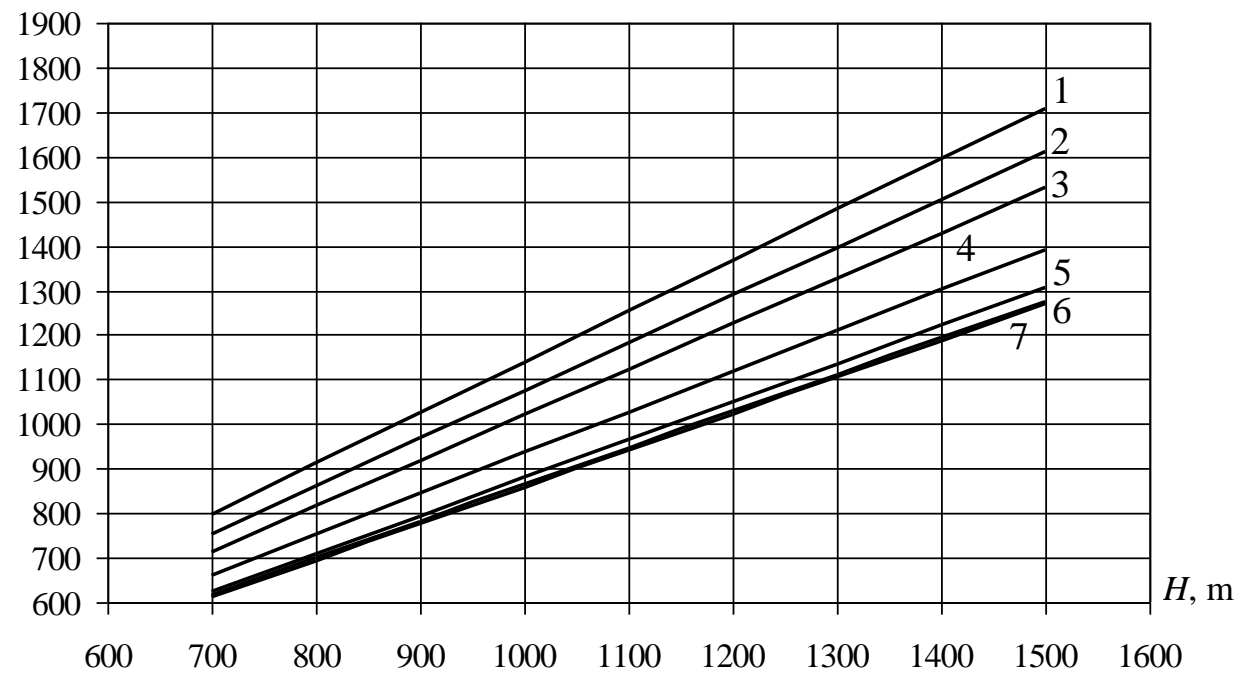

Fig. 5. Graphs of changes in the floor displacement values depending upon the mine working depth if anchor length is $3.5 \mathrm{~m}: 1-3$ anchors, $2-4$ anchors, $3-5$ anchors, $4-6$ anchors, $5-7$ anchors, $6-8$ anchors, $7-9$ anchors 
- when the mine working deepens, difference between roof displacements (if 2.2$3.5 \mathrm{~m}$ anchors are applied) increases when the number of the anchors is $3,5,7$, and 9 respectively becoming as follows: 77, 57, 29, and $21 \mathrm{~mm}$ at $700 \mathrm{~m}$ depth (Fig. 6, $a$ ), and 196, 198, 217, and $210 \mathrm{~mm}$ at $1500 \mathrm{~m}$ depth (Fig. 6, b);

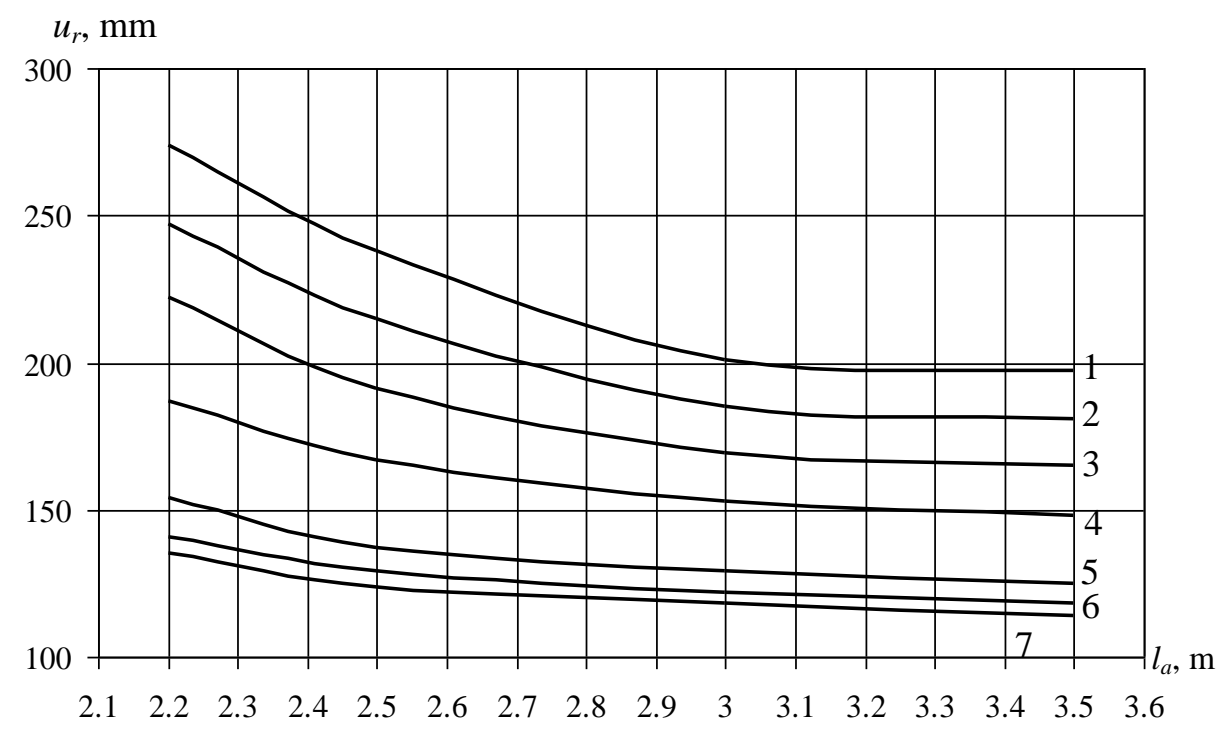

a)

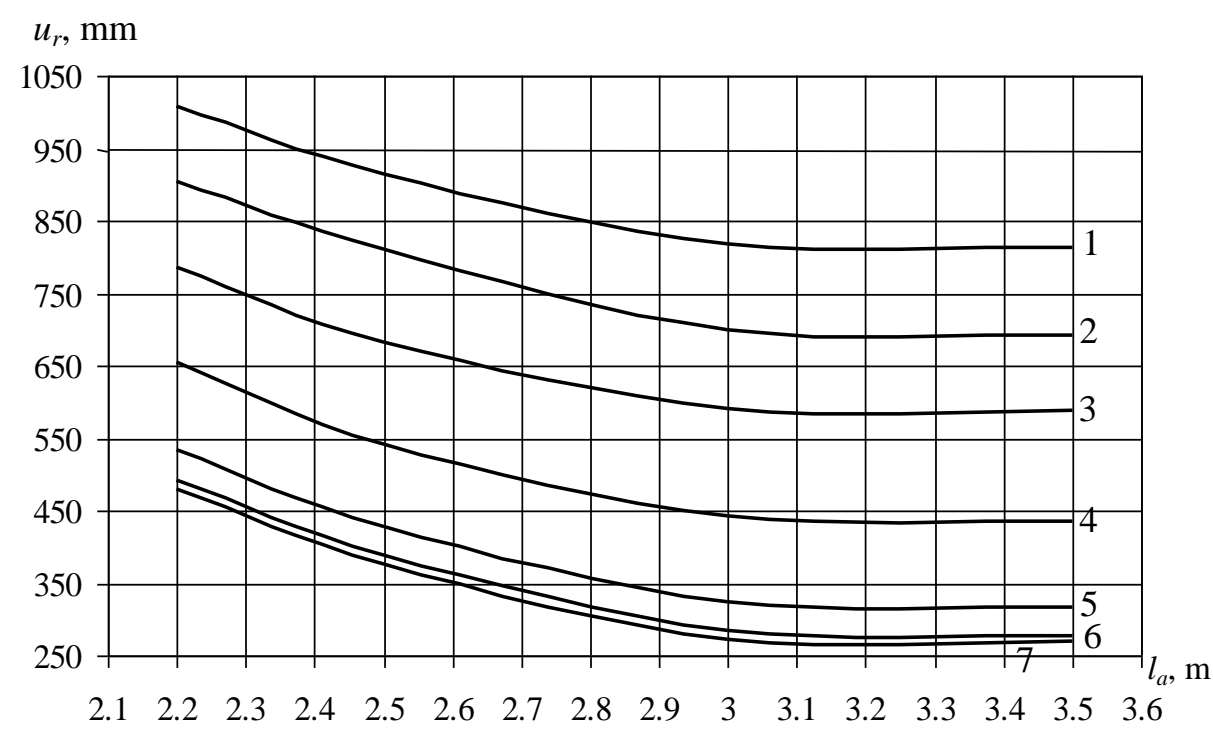

b)

Fig. 6. Graphs of roof displacement value variations depending upon the anchor length when the mine working depth is: $\mathrm{a}-700 \mathrm{~m}$, and $\mathrm{b}-1500 \mathrm{~m}$ (1-3 anchors, $2-4$ anchors, $3-5$ anchors, $4-6$ anchors, $5-7$ anchors, $6-8$ anchors, $7-9$ anchors)

- roof displacement value decreases if 2.2-3.5 m (700 m depth) variation of the anchor length takes place which is described by means of the polynomial dependence:

$$
\begin{gathered}
u_{r}=63.1 l_{a}^{2}-419.19 l_{a}+891.07 \text { for } N_{a}=3 \text { anchors, } \\
u_{r}=49.023 l_{a}^{2}-321.97 l_{a}+691.92 \text { for } N_{a}=5 \text { anchors, } \\
u_{r}=22.615 l_{a}^{2}-149.75 l_{a}+372.7 \text { for } N_{a}=7 \text { anchors, } \\
u_{r}=13.156 l_{a}^{2}-90.224 l_{a}+269.01 \text { for } N_{a}=9 \text { anchors; }
\end{gathered}
$$


- roof displacement value decreases if 2.2-3.5 m (1500 m depth) variation of the anchor length takes place which is described by means of the polynomial dependence:

$u_{r}=173.07 l_{a}^{2}-1138.2 l_{a}+2675.1$ for $N_{a}=3$ anchors,

$u_{r}=185.22 l_{a}^{2}-1207.4 l_{a}+2545.1$ for $N_{a}=5$ anchors,

$u_{r}=192.53 l_{a}^{2}-1264.7 l_{a}+2384.8$ for $N_{a}=7$ anchors,

$u_{r}=188.06 l_{a}^{2}-1234.7 l_{a}+2286.1$ for $N_{a}=9$ anchors;

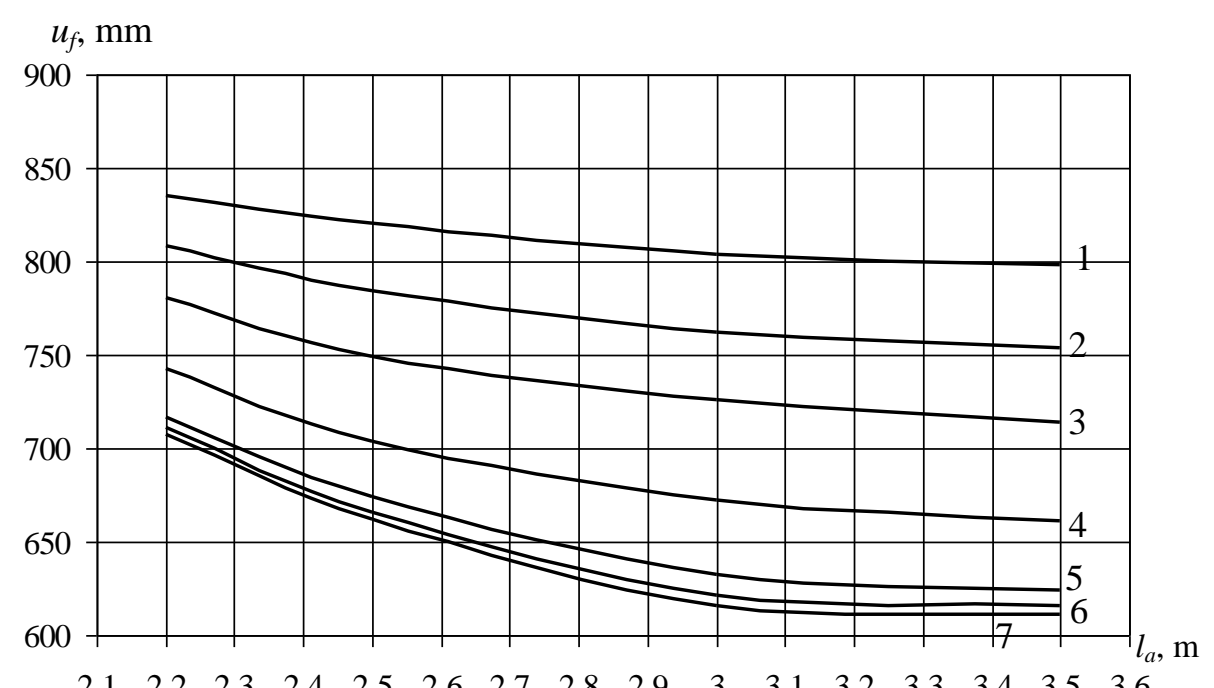

a)

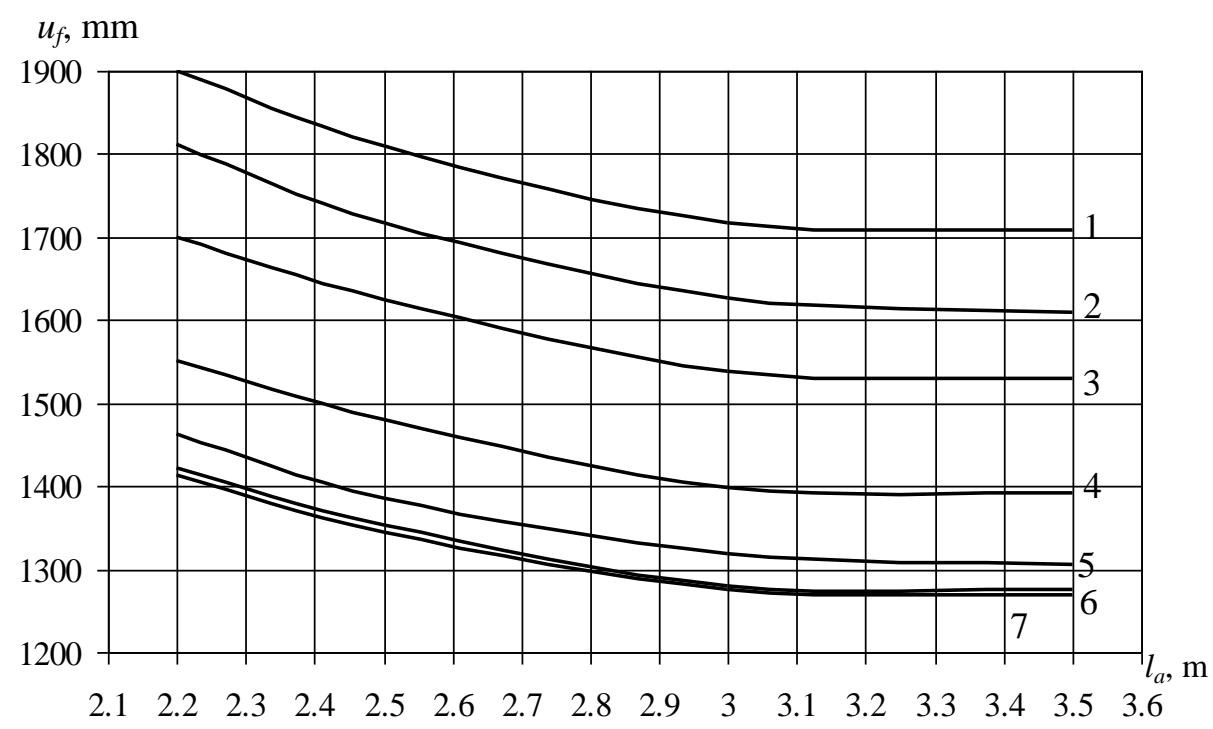

b)

Fig. 7. Graphs of floor displacement value variations depending upon the anchor length when the mine working depth is: $\mathrm{a}-700 \mathrm{~m}$, and $\mathrm{b}-1500 \mathrm{~m}$ (1-3 anchors, $2-4$ anchors, $3-5$ anchors, $4-6$ anchors, $5-7$ anchors, $6-8$ anchors, $7-9$ anchors)

- when the mine working deepens, difference between floor displacements (if 2.2$3.5 \mathrm{~m}$ anchors are applied) increases when the number of the anchors is 3, 5, 7, and 9 respectively becoming as follows: 37, 67, 93, and $96 \mathrm{~mm}$ at $700 \mathrm{~m}$ depth (Fig. 7, a), and 191, 169, 157, and $145 \mathrm{~mm}$ at $1500 \mathrm{~m}$ depth (Fig. 7, b); 
- floor displacement value decreases if 2.2-3.5 m (700 m depth) variation of the anchor length takes place which is described by means of the polynomial dependence:

$$
\begin{gathered}
u_{f}=20.853 l_{a}^{2}-147.24 l_{a}+1057.9 \text { for } N_{a}=3 \text { anchors, } \\
u_{f}=40.368 l_{a}^{2}-279.8 l_{a}+1199.6 \text { for } N_{a}=5 \text { anchors, } \\
u_{f}=70.104 l_{a}^{2}-470.92 l_{a}+1413.5 \text { for } N_{a}=7 \text { anchors, } \\
u_{f}=78.759 l_{a}^{2}-523.09 l_{a}+1476.9 \text { for } N_{a}=9 \text { anchors; }
\end{gathered}
$$

- floor displacement value decreases if 2.2-3.5 m (1500 m depth) variation of the anchor length takes place which is described by means of the polynomial dependence:

$$
\begin{aligned}
& u_{f}=163.36 l_{a}^{2}-1078.9 l_{a}+3483.7 \text { for } N_{a}=3 \text { anchors, } \\
& u_{f}=135.08 l_{a}^{2}-902.26 l_{a}+3032.2 \text { for } N_{a}=5 \text { anchors, } \\
& u_{f}=123.47 l_{a}^{2}-822.99 l_{a}+2674.6 \text { for } N_{a}=7 \text { anchors, } \\
& u_{f}=122.71 l_{a}^{2}-811.52 l_{a}+2605.9 \text { for } N_{a}=9 \text { anchors; }
\end{aligned}
$$

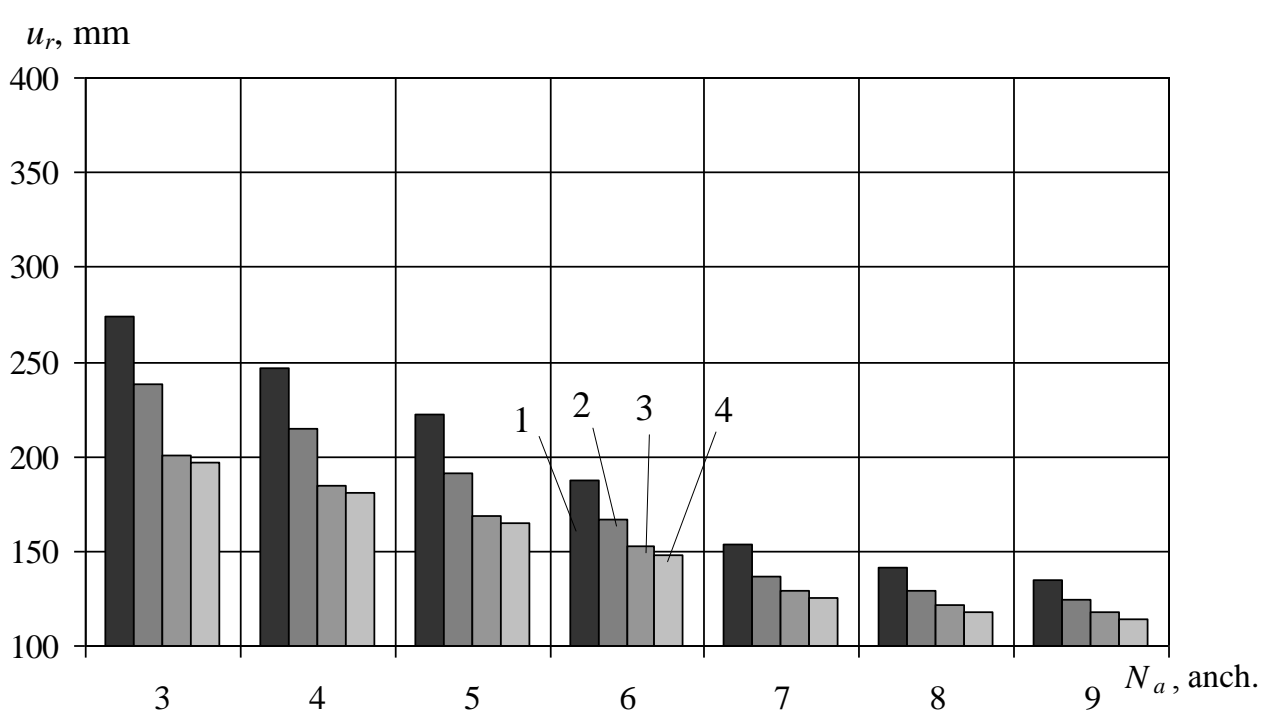

a)

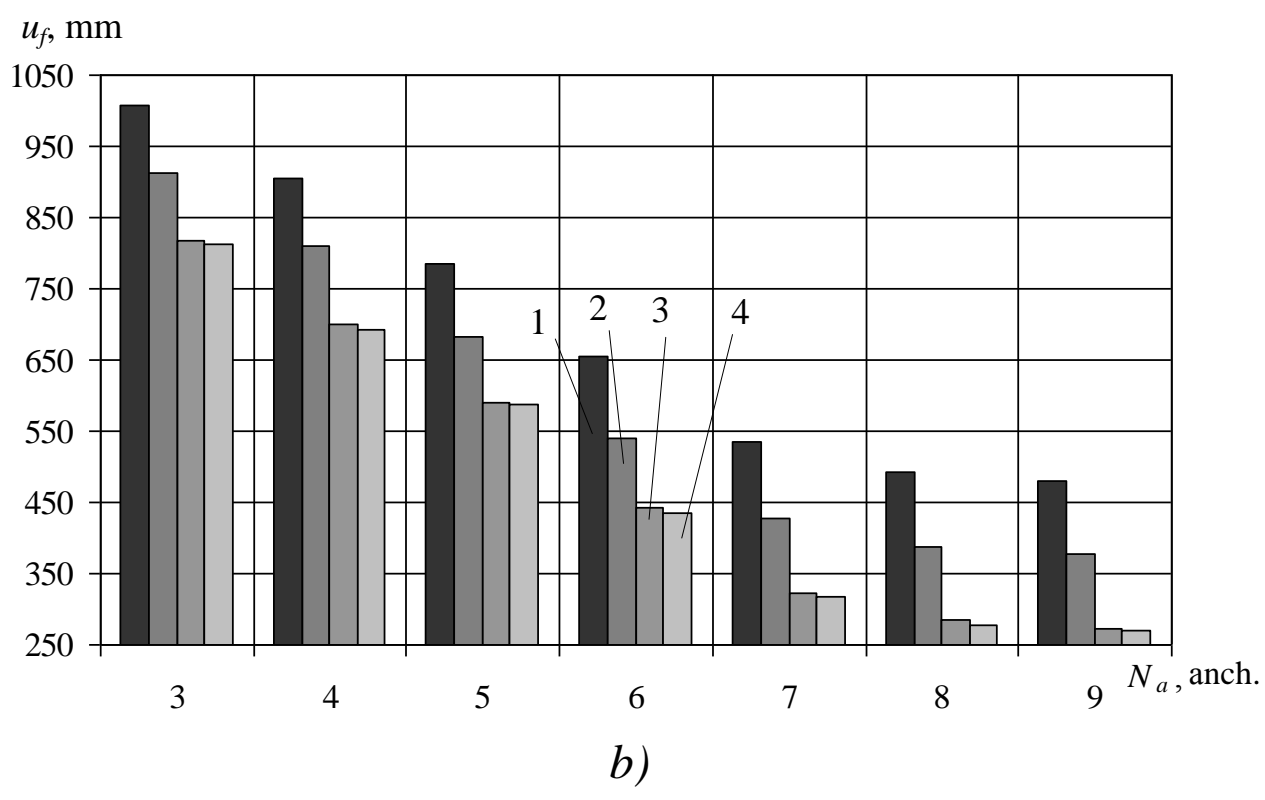

Fig. 8. Graphs of roof displacement value variations depending upon the anchor number when the mine working depth is: $\mathrm{a}-700 \mathrm{~m}$, and $\mathrm{b}-1500 \mathrm{~m}$

$$
\left(1-l_{a}=2.2 \mathrm{~m}, 2-l_{a}=2.5 \mathrm{~m}, 3-l_{a}=3.0 \mathrm{~m} \text {, and } 4-l_{a}=3.5 \mathrm{~m}\right)
$$



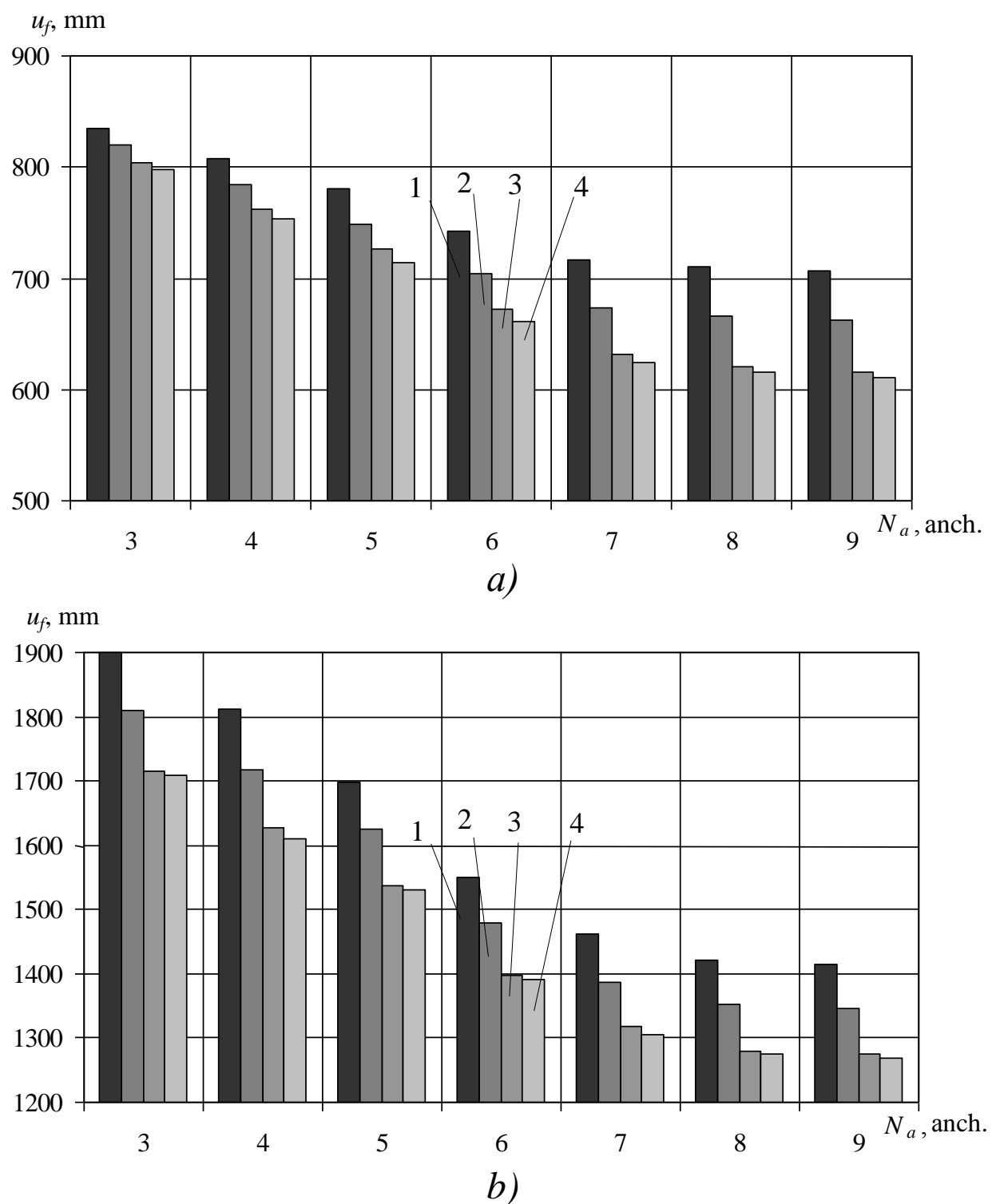

Fig. 9. Graphs of a floor displacement value variations depending upon the anchor number when the mine working depth is: $\mathrm{a}-700 \mathrm{~m}$, and $\mathrm{b}-1500 \mathrm{~m}$ $\left(1-l_{\mathrm{a}}=2.2 \mathrm{~m}, 2-\mathrm{l}_{\mathrm{a}}=2.5 \mathrm{~m}, 3-\mathrm{l}_{\mathrm{a}}=3.0 \mathrm{~m}\right.$, and $\left.4-\mathrm{l}_{\mathrm{a}}=3.5 \mathrm{~m}\right)$

- when deepening of a mine working increases, difference between roof displacements (if 3 to 9 anchors are applied) increases too when 2.2, 2.5, 3.0, and $3.5 \mathrm{~m}$ anchors are used respectively becoming as follows: $139,114,83$, and $83 \mathrm{~mm}$ at $700 \mathrm{~m}$ depth (Fig. 8, a), and 529, 536, 544, and $543 \mathrm{~mm}$ at $1500 \mathrm{~m}$ depth (Fig. 8, b);

- roof displacement values decrease if the anchor number varies from 3 to 9 (700 $\mathrm{m}$ depth) being described with the help of the polynomial dependence:

$$
\begin{gathered}
u_{f}=0.9722 N_{a}{ }^{3}-9.6548 N_{a}{ }^{2}-1.127 N_{a}+283 \text { for } l_{a}=2.2 \mathrm{~m}, \\
u_{f}=0.7222 N_{a}{ }^{3}-6.7857 N_{a}{ }^{2}-5.7222 N_{a}+249.29 \text { for } l_{a}=2.5 \mathrm{~m}, \\
u_{f}=0.5556 N_{a}{ }^{3}-5.6071 N_{a}{ }^{2}-0.5198 N_{a}+205.86 \text { for } l_{a}=3.0 \mathrm{~m}, \\
u_{f}=0.5556 N_{a}{ }^{3}-5.5595 N_{a}{ }^{2}-0.9008 N_{a}+202.29 \text { for } l_{a}=3.5 \mathrm{~m} ;
\end{gathered}
$$

- roof displacement values decrease if the anchor number varies from 3 to 9 (1500 $\mathrm{m}$ depth) being described with the help of the polynomial dependence:

$$
u_{f}=3.7778 N_{a}{ }^{3}-35.202 N_{a}{ }^{2}-21.337 N_{a}+1060.6 \text { for } l_{a}=2.2 \mathrm{~m} \text {, }
$$




$$
\begin{gathered}
u_{f}=3.9722 N_{a}{ }^{3}-36.286 N_{a}^{2}-24.972 N_{a}+972.14 \text { for } l_{a}=2.5 \mathrm{~m}, \\
u_{f}=3.8611 N_{a}{ }^{3}-35.19 N_{a}^{2}-28.337 N_{a}+875 \text { for } l_{a}=3.0 \mathrm{~m}, \\
u_{f}=3.9722 N_{a}{ }^{3}-36.31 N_{a}^{2}-25.496 N_{a}+867.43 \text { for } l_{a}=3.5 \mathrm{~m} ;
\end{gathered}
$$

- when the mine working deepens, difference between its floor displacements (if 33 to 9 anchors are used) increases when 2.2, 2.5, 3.0, and $3.5 \mathrm{~m}$ anchors are applied respectively becoming as follows: $128,158,188$, and $187 \mathrm{~mm}$ at $700 \mathrm{~m}$ depth (Fig. 9, $a$ ), and 486, 464, 441, and $440 \mathrm{~mm}$ at $1500 \mathrm{~m}$ depth (Fig. 9, $b$ );

- the mine working floor displacement value decreases if the anchor number varies from 3 to 9 (700 $\mathrm{m}$ depth) being described with the help of the polynomial dependence:

$$
\begin{gathered}
u_{f}=0.9167 N_{a}{ }^{3}-8.0952 N_{a}{ }^{2}-8.5833 N_{a}+851 \text { for } l_{a}=2.2 \mathrm{~m}, \\
u_{f}=0.9722 N_{a}{ }^{3}-7.7976 N_{a}{ }^{2}-19.127 N_{a}+846.29 \text { for } l_{a}=2.5 \mathrm{~m}, \\
u_{f}=1.3056 N_{a}{ }^{3}-11.643 N_{a}{ }^{2}-12.234 N_{a}+826 \text { for } l_{a}=3.0 \mathrm{~m}, \\
u_{f}=1.1389 N_{a}{ }^{3}-9.0595 N_{a}{ }^{2}-23.27 N_{a}+829.29 \text { for } l_{a}=3.5 \mathrm{~m} ;
\end{gathered}
$$

- the mine working floor displacement value decreases if the anchor number varies from 3 to 9 (1500 $\mathrm{m}$ depth) being described with the help of the polynomial dependence:

$$
\begin{aligned}
u_{f} & =3.9167 N_{a}{ }^{3}-36.524 N_{a}^{2}-11.655 N_{a}+1947 \text { for } l_{a}=2.2 \mathrm{~m}, \\
u_{f} & =3.8889 N_{a}{ }^{3}-36.94 N_{a}{ }^{2}-2.6865 N_{a}+1844.6 \text { for } l_{a}=2.5 \mathrm{~m}, \\
u_{f} & =3.4722 N_{a}{ }^{3}-32.238 N_{a}{ }^{2}-12.925 N_{a}+1758 \text { for } l_{a}=3.0 \mathrm{~m}, \\
u_{f} & =3.2778 N_{a}{ }^{3}-29.643 N_{a}{ }^{2}-22.135 N_{a}+1756 \text { for } l_{a}=3.5 \mathrm{~m} ;
\end{aligned}
$$

- in the context of mining and geological conditions of $l_{3}$ seam in Novodonetska mine, rational anchoring density is almost $0.7-0.75$ anchors $/ \mathrm{m}^{2}\left(N_{a}=7\right.$ anchors), and rational length of anchors set up within a mine working roof is almost $l_{a}=2.8-3.1 \mathrm{~m}$.

Conclusions and tendencies for future research. Thus, the dependences of displacements of the inclined mine working roof and floor upon its depth (700-1500 m) in terms of anchor length variation (2.2-2.5 m) as well as anchoring density (3-9 anchors) have been obtained. The dependences may be used to forecast displacements in the design process for the inclined mine workings $l_{3}$ in Novodonetska mine or under similar mining and geological conditions of the inclined mine workings, which will be constructed, in the process of the development of their maps and support. It has already been determined that rational anchoring density for the inclined mine working roof (under the mining and geological conditions of $l_{3}$ seam in Novodonetska mine and rational length of anchors, set up within the inclined mine working roof), is almost $l_{a}=2.8-3.1 \mathrm{~m}$.

Further research will be aimed at the analysis and generalization of technologically and economically substantiated rational parameters for the inclined mine workings under the mining and geological conditions of DTEK Dobropilliavuhillia JSC.

\section{References}

1. Булат, А.Ф. (2014) Передові технології кріплення гірничих виробок вугільних шахт України. Вісник НАН Украӥни, 1, 74-79. doi:10.15407/visn2014.01.074

2. Булат, А.Ф., Попович, І.М., Вівчаренко, О.В., \& Круковський, О.П. (2014) Технологія анкерного кріплення гірничих виробок на шахтах України: стан і перспективи. Уголь Украuнbl, 2, 3-7. 
3. Круковский, А.П. (2011) Анализ влияния плотности установки анкерной крепи на состояние приконтурных пород выработки арочного сечения. Геотехническая механика: Межвед. сб. науч. тр., 94, 95-104.

4. Круковский, А.П. (2014) Технология опорно-анкерного крепления горных выработок угольных шахт. Научно-техническое обеспечение горного производства: Сб. тр. ИГД им. Д.А. Кунаева, 86, 26-33.

5. СОУ 10.1.05411357.010:2014. “Система забезпечення надійного та безпечного функиіонування гірничих виробок із анкерним кріпленням. Загальні технічні вимоги” (2014) Міненерговугілля України : ІГТМ НАН України.

6. Терещук, Р.Н., \& Терещук, О.В. (2014) Определение рациональных параметров анкерования наклонных выработок. Сучасні ресурсоенергозберігаючі технології гірничого виробниитва, 2 (14), 104-113.

7. Терещук, Р.Н. (2015) Моделирование анкерных систем для крепления наклонных выработок. Сучасні ресурсоенергозберігаючі технології гірничого виробництва, 2 (16), 81-90.

8. Терещук, Р.М. (2017) Кріплення похилих виробок анкерними системами. Сучасні ресурсоенергозберігаючі технології гірничого виробництва, Вип. 2 (20), 50-60.

9. Tereshchuk, R.M., Khoziaikina, N.V., \& Babets, D.V. (2018) Substantiation of rational roof-bolting parameters. Scientific bulletin of National Mining University, 1, 19-26.

10. Терещук, Р.М. (2018) Дослідження параметрів анкерних систем для кріплення похилих виробок. Вісник Житомирського державного технологічного університету. Серія: Технічні науки, 2 (82), 268-276.

doi:10.26642/tn-2018-2(82)-268-276

\section{АНОТАЦІЯ}

Мета. Дослідити стан приконтурного породного масиву похилої виробки, що закріплена анкерними системами, з використанням математичних методів моделювання, і на основі результатів досліджень визначити раціональну щільність анкерування і довжину анкерних штанг при збільшенні глибини эї закладення в гірничо-геологічних умовах пласта $l_{3}$ шахти «Новодонецька» ТОВ «ДТЕК Добропіллявугілля».

Методи дослідження. Обгрунтування параметрів анкерних систем для похилих виробок виконувалося шляхом дослідження закономірностей зміни поведінки та напружено-деформованого стану породного масиву і отримання зміщень породного контуру гірничої виробки, та на їх основі визначення раціональних величин довжини анкерних штанг і щільності анкерування. Для досліджень змін поведінки та напружено-деформованого стану приконтурного породного масиву похилої виробки, що закріплена анкерними системами, використовувався метод скінченних елементів.

Результати дослідження. Розроблена розрахункова схема до вирішення задачі визначення раціональної щільності анкерування та довжини анкерів для кріплення похилих виробок при зміні глибини їх закладення в гірничо-геологічних умов пласта $l_{3}$ шахти «Новодонецька». Визначено раціональні параметри анкерних систем, при кріпленні похилих гірничих виробок в конкретних гірничо-геологічним умовах.

Наукова новизна. Отримано графіки залежностей зміщень породного контуру покрівлі та підошви похилої виробки від глибини ії закладення при варіюванні довжини анкерних штанг та щільності анкерування для гірничо-геологічних умов пласта $l_{3}$ шахти «Новодонецька».

Практична значимість. Результати досліджень можуть бути використані на стадії проектування для прогнозу зміщень покрівлі, підошви та боків похилих виробок в гірничо-геологічних умовах пласта $l_{3}$ шахти «Новодонецька» для оптимізації параметрів анкерних систем. 
Ключові слова: похила виробка, математичне моделювання, анкерне кріплення, щільність, довжина.

\section{АННОТАЦИЯ}

Цель. Исследовать состояние приконтурного породного массива наклонной выработки, закрепленной анкерными системами с использованием математических методов моделирования и на основе результатов исследований определить рациональную плотность анкерования и длину анкерных штанг при увеличении глубины ее заложения в горно-геологических условиях пласта $l_{3}$ шахты «Новодонецкая» ООО «ДТЭК Добропольеуголь».

Методы исследований. Обоснование параметров анкерных систем для наклонных выработок выполнялось путем исследования закономерностей изменения поведения и напряженно-деформированного состояния породного массива и получения смещений породного контура горной выработки, и на их основе определения рациональных величин длины анкерных штанг и плотности анкерования. Для исследований изменений поведения и напряженно-деформированного состояния приконтурного породного массива наклонной выработки, закрепленной анкерными системами, использовался метод конечных элементов.

Результаты исследований. Разработана расчетная схема к решению задачи определения рациональной плотности анкерования и длины анкеров для крепления наклонных выработок при изменении глубины их заложения в горно-геологических условий пласта $l_{3}$ шахты «Новодонецкая». Определены рациональные параметры анкерных систем, при креплении наклонных горных выработок в конкретных горно-геологических условиях.

Научная новизна. Получены графики зависимостей смещений породного контура кровли и почвы наклонной выработки от глубины ее заложения при варьировании длины анкерных штанг и плотности анкерования для горно-геологических условий пласта $l_{3}$ шахты «Новодонецкая».

Практическая значимость. Результаты исследований могут быть использованы на стадии проектирования для прогноза смещений кровли, почвы и боков наклонных выработок в горногеологических условиях пласта $l_{3}$ шахты «Новодонецкая» для оптимизации параметров анкерных систем.

Ключевые слова: наклонная выработка, математическое моделирование, анкерная крепь, плотность, длина. 